\title{
The search for interreligious convivance, ongoing challenge and charge
}

J D Gort ${ }^{1}$

(Free University of Amsterdam)

\section{ABSTRACT \\ The search for interreligious convivance, ongoing challenge and charge}

This essay deals with the relationship between Christianity and other religions. Part one looks briefly at the matter of religion itself. Part two provides a condensed historical survey of the attitude of Christianity toward the world outside itself: the approach of the church to other religions changed from initial appreciation through a long phase of rejection to an increasingly affirmative posture in recent times. This shift is explained by a number of causal factors that gave rise to new understandings regarding God's work in the world and Christian mission, which in turn led to the emergence of various theologies of religion. The question confronting religious people today is how to foster the removal of interhuman divisions and the promotion of justice and peace. One potential means of achieving this goal is interreligious dialogue. In part three, the author delineates his concept of the four facets of dialogue: that of histories, of theologies, of spiritualities, and of life. Dialogue at all four of these levels is key to the establishment of interreligious convivance, which in our present world is prerequisite to the security and well-being of humanity.

In this essay I would like to touch briefly on the historical and contemporary attitudes of Christianity toward other religions and then sketch out what in my view are the four main levels of interreligious dialogue. But before going into these two matters it would be well to begin with a few preliminary remarks about religion in general.

\section{RELIGION}

Though some, particularly but certainly not only in the West, assert

1 Jerald D Gort is Associate Professor of Missiology (emeritus) at the Faculty of Theology, Free University of Amsterdam. He has published in the areas of mission studies, ecumenics and theology of religion and is co-founder and co-editor of the Amsterdam academic series Currents of Encounter. 
that religion is passé and claim that it is on the way out, it will be quite clear to any objective observer that religion, far from being on the verge of extinction, is ubiquitous right throughout the contemporary world and continues to be vitally important to the vast majority of people on earth. Humans have always tried to deal with and come to some understanding of the wonder and inscrutability of their own and the lives of others, of nature and of the universe. And people today carry on this quest, posing the same essentially religious questions that their forbears did in times past: "How can I understand the hidden forces that play upon my life? How can I deal with the mysterious power which is sometimes so near...and at other times so far away...?" (Bach 1961:7).

According to the well-known Dutch missiologist J H Bavinck, all humans are provided with a "religious consciousness" which entails a deep awareness of a number of fundamental riddles, including the enigma of individual existence coupled with a sense of all-embracing cosmic cohesion or the all-inclusive "totality of heaven and earth"; the puzzle of the origin and impinging claims of morals and norms; the mystery of the conviction that things are not the way they ought to be and the concomitant universal longing for redemption; the question of the "invisible background" of all things visible; and the ambiguity of human life itself (cf Bavinck 1966:107111). In the end all of these riddles coalesce into one profoundly religious question to which people everywhere seek an answer: "Who am I, small mortal man, in the midst of all these powerful realities with which my life is most intimately related?" (Bavinck $1966: 113)^{2}$. Corollary to this "religious consciousness" and the questions and riddles it engenders, humans, wherever they live, engage in one or another form of worship or religious observance. "No people or tribe is without religion, however variously it finds expression and even if it has not been specifically identified by name" (Sundermeier 1991:856). Religious experience, belief and expression are woven into the very fabric of human nature and life.

There are those, chiefly in modern times, who view religions and religion in general in negative, sometimes exceedingly negative, terms. And, of course, it cannot be denied that religions have been and in some cases continue to be stamped by ambiguity with respect

2 See Bavinck (1989:12-75) for an extensive discussion of his concept of religious consciousness and its component riddles. 
to right and wrong, good and evil. Religions have often exhibited a strange capacity for betrayal of their central teachings and have been or still are guilty of collusion with harmful forces. One need only mention NGK Apartheid theology or contemporary Islamist extremism or "Christian" free-for-all market capitalism" ${ }^{3}$ as examples of the many other instances of this type of religious infidelity and complicity found throughout history and the present world. It must be recognised that religion "as a social phenomenon...was, is and will be a contributory factor to conflict" (O'Grady \& Scherle 2007:17). Notwithstanding this potential for degeneration shared by all religions, however, it is clear that religion as such is vitally important to the vast majority of human beings. People in all times and places, thus, appear to have had and to have the need to commune with a Supreme Being or respond to a Transcendent Power of one kind or another. Most people cannot get along without religion as a means of coping with existential disquietude and as a medium of faith and hope ${ }^{4}$.

Though it is true that religion is found everywhere, it has proven impossible to formulate a definition of religion that is universally acceptable. From a theocentric point of view it may be said that religion takes its rise from a divinely initiated encounter of people with God or the Sacred or the Holy. But this is of course only a possible explanation of the origin of religion and does not constitute a definition of it. Since the scope of this essay does not allow for a detailed examination of the many existing definitions of religion, simple mention of three examples, which may be considered to be more or less useful, will have to suffice. J McDowell (1983:11) states concisely that religion is "that aspect of one's experience in which [one] attempts to live harmoniously with the power or powers [one] believes are controlling the world". Louis Lutzbetak, writes

3 What is meant here by "free-for-all" Capitalism is a politico-economic system which is grounded in and governed by a putative transcendent "law" of profit and gain and hence is incapable of taking any essential account of categories and principles of legitimacy and illegitimacy other than those directly associated with or dictated by this "immutable law", a system, thus, that can only breed greed and exploitation.

4 On the ambiguity of religion, their capacity for effecting both evil and good, for being both demonic and redemptive see further Gort \& Vroom (2002). 
that religion can be "defined as a system of beliefs and practices by which a group of people, in a culturally approved relationship with supernatural beings or powers, struggles with ultimate problems of human life" (Lutzbetak 1998:264). And, finally, John O'Grady and Peter Scherle define religion "as a form of communication of human beings in which a specific coherent meaning of the world as a whole is expressed through speech, acts and artifacts, and which assumes the participation of a divine reality in this human communication" (O’Grady \& Scherle 2007:5, 6) .

\section{CHRISTIANITY AND THE OTHER RELIGIONS}

We now turn to an examination of the way in which Christianity has related to the other religions of the world, beginning with a condensed survey of historical Christian attitudes toward other traditions, followed by a review of the shifting stance of Christianity vis-à-vis people of other faiths and the religious creeds and practices to which they adhere.

\subsection{Historical attitudes}

For most of its history the opinion of Christianity with respect to the world, other cultures, other religious traditions and their adherents was overwhelmingly negative. During the earliest period of its existence, however, it had exhibited an altogether different spirit. At that time, leading Christian thinkers such as the gifted Apologists, Justin Martyr (c 100 - c 165) and Clement of Alexandria (c 150 - c 215), showed a great deal of esteem for the faiths of other people.

These Apostolic "Church Fathers" argued that through the operation of God's salvific grace many good and true things had come into being everywhere in the world. They were persuaded that the philosophical and religious traditions of humankind owe their existence to God's revelatory initiative. Making use of various concepts and insights borrowed from the Greek Stoic school of philosophy, they taught that all humans have been gifted with a logos spermatikos (a seed of the Logos found in the human soul) through

5 In this same context they offer an interesting description of theology: "Theology is rooted in a religious community and is a critical self-reflection on the way in which communication of the divine takes place within religious communication. Theology, reflecting on God talking within human God-talk, seeks to offer, as it were, a vertical dimension that keeps the horizontal true" (O'Grady and Scherle 2007:6). 
which they participate in the eternal divine Logos, whom the Apologists identified with Christ. They argued, further, that the religious and philosophical traditions of humankind could function as a praeparatio evangelica (preparation for the gospel) and as paedagogoi (instructors) which make people receptive to the fullness of the truth revealed by God in Christ. Clement maintained that Indian Hindu philosophy was eminently capable of preparing the nations for the gospel and effecting openness among their peoples for the good news concerning Christ.

Unfortunately, this generosity of mind that made it possible to hold the beliefs and convictions of others in such high regard was nipped in the bud before it could fully flower or bear ripened fruit. From about the middle of the third century the affirmative openness that had informed much of early patristic theology gradually gave way to increasingly negative feelings on the part of the church toward the exterior world, feelings based on certain scriptural interpretations and theological notions. A second phase in the history of the church's attitude to other cultural and religious traditions began to emerge, the watch-word of which became extra ecclesiam nulla salus (outside the church no salvation).

As originally formulated by Origen (c 185 - c 254) this maxim was pastoral in intent and purpose. Before long, however, it was given a dogmatic, stringently minimalist-exclusionist twist by Cyprian of Carthage $(\dagger 258)$, who contended that no salvation whatever is to be found outside the boundaries of the hierarchical Christian church: "He cannot have God for his Father," he wrote, "who does not have the Church for his mother" (cited in Kelly 1965:206). Subsequent to, and as a consequence of, the gradual establishment of Christianity as the official religion of the Roman Empire from around A D 350, this exclusionist rigorism hardened even further. The religions and cultures of other people came to be viewed as "non-Christian" and perceived as expressions of heathen unbelief and evil superstition. The 'outside world' came to be seen as the kingdom of darkness requiring to be taken up into the enlightened corpus Christianum. For the next 1500 years or more Christian thinking in respect of other religions would be almost wholly governed by that perception,

There were, of course, those who now and again challenged the prevailing mood by advocating or employing a more accommodating model of encounter with other religions, for example, Pope 
Gregory the Great (c 540-604), Raymond Lull (c 1235 -c 1315), Bartholomew de las Casas (1474-1566), Matteo Ricci (1552-1610), Robert de Nobili (1577-1656) and others. And even in the $19^{\text {th }}$ century, when missions and European colonial expansion were often very nearly hand in glove, a few voices were raised in protest against the generally antagonistic attitude of Christianity toward the religions of Asia and Africa. Yet all such challenges went largely unheeded. The overall picture shows that up until recent times the confrontation model continued virtually unabated, and that when encountering other religious traditions, Christianity frequently allowed its attitude to be guided by unbridled feelings of superiority. The last few decades, however, have witnessed a gradual change of outlook in this regard.

\subsection{Shifting stance}

Since roughly the 60's of the previous century Christianity has become more and more open toward and appreciative of other religions. There are many external factors that contributed to this evolving transformation of Christian thinking with regard to other faiths and their adherents.

\subsubsection{External causal influences}

One of the more important of these outside factors is the huge amount of vastly improved intelligence about other religious traditions that has become available in modern times. Earlier, the church's knowledge of the other religions was very limited, and the scanty information it did have about them was in most cases highly inaccurate. But from around 1860 onward Christian scholars began to undertake serious academic studies of the other great faiths of the world for purposes of providing a better understanding of them.

A second factor that helped to activate this metamorphosis of attitude toward other religions was the increasing awareness of the continued existence and conspicuous vigor of these religions, despite hundreds of years of Christian missionary activity. The operating presupposition of many Western Christians had been that the church and its allied missionary agencies were called to enlighten and civilise the benighted heathen peoples of the world, people existing in a state of intellectual, moral, social and religious darkness. But now the obvious continuing vitality of the other faith traditions began to bewilder the church and set people thinking (cf Rahner 1962:137-138). 
Coupled with this was, in the third place, the breakdown of European pre-eminence in human affairs as a result of, among other things, the $20^{\text {th }}$ century wars of destruction among the so-called "Christian" nations of the Occident and the post-World War II process of decolonization along with Asian and African nationbuilding. Europe as imperial and colonial centre, waxing for so long, was now clearly on the wane. This, too, forced Christianity to a reappraisal not only of its own position in the world but even more significantly of that of other religious traditions as well.

A fourth factor that has figured strongly in the change of attitude among Christians toward other religions is the radical religious pluralism of populaces and communities all over the globe. Virtually everywhere nowadays religions have become mutually accessible, which means, in the words of David Bosch, that "today few Christians anywhere in the world find themselves in a situation where coexistence with other religionists is not part and parcel of their daily life" (Bosch 1991:483). This new proximity to the beliefs of people of other faiths has been another key factor in the arousal of Christian interest in them.

\subsubsection{Internal causal factor}

It is within the framework of external causal influences such as those we have just reviewed that a re-examination of theological positions and biblical interpretations has taken place within both RC theology and Protestant ecumenical thought. This reassessment was undertaken with a view to finding answers to a number of cardinal questions that need to be addressed in any meaningful attempt to ascertain the proper Christian attitude toward other religions.

First, do people beyond Christianity and the Christian gospel have a share in salvation, and if so, what does that salvation consist of? Is "salvation" even a major concern of other religions? What are the aims of life in other religious traditions? Second, if the Christian gospel may be said to bear definitive truth and to have decisive importance and universal validity, does this mean that other messages of human and divine salvation are null and void? Third, what is "the significance of the religious experiences of people who do not know Christ?" (Reitsma 1999:2). If Christians say that their "experiences of faith are experiences with the only true God, the Father of Jesus Christ," are they then "obliged to go on to say that the experiences of others are not true?" (:2). Fourth, can other 
religions be viewed as viae salutis, salvific ways, transmitters of human well-being and good? Fifth, if other religions constitute ways to salvation, is there still a raison d'être for Christian mission? These questions bear far-reaching implications: the answers Christians give to them will be of pivotal significance in determining their attitude toward people whose religious experience is rooted in other faith traditions.

\subsection{New understandings}

As indicated, increased knowledge of and close proximity to other religions has led to a great deal of fresh theological reflection among Christians in recent years. What has this process of reassessment generated in terms of new insights on matters pertinent to the question of the proper attitude of Christianity vis-à-vis other faith traditions?

\subsubsection{God's work among God's people}

An awareness has been growing that this world is the theatrum Dei. God has left Himself nowhere without witness. As the Black Spiritual has it: "He's got the world in His hands, He's got the whole world in His hands" In the words of Bavinck (1966:200):

God knows every human being. Buddha would never have meditated on the Way of Deliverance if God had not touched him. Mohammed would never have delivered his prophetic witness if God had not been working with him. Every religion contains within it the quiet, secret work of God in one form or another.

The world and all its people, being God's creation, are the permanent object of God's inexhaustible love and salvific concern. According to the $6^{\text {th }}$ Assembly of the WCC in Vancouver in 1983, the whole of human history, at every possible level and in every time and place, with all of its cultures and forms of faith, with all of its tribes and peoples, with all of its dark and lustrous, destructive and creative aspects is and remains the arena of the activity of the triune God, Father, Son, and Holy Spirit. And this is an insight that is being embraced by more and more Christians as time goes on.

In Isaiah 65:1 Yahweh declares: "I was ready to be sought out by those who did not ask, to be found by those who did not seek me. I said, 'Here I am, here I am,' to a nation that did not call on my name". Commenting on these words of the prophet, Eberhard Jüngel 
rightly states, “....in Jesus Christ God speaks in this way to all nations, to the whole world" (Jüngel 2000:206). Further along this line, according to the late Indian lay theologian M M Thomas, Christian spirituality is necessarily Christ-centered, and this spirituality does not lead to withdrawal from but to affirmation of the world, because, as taught by the biblical witness, "what God has done in Christ is for the world" (cf Chacko 2000:66). This, says Thomas, is of great significance for determining the proper attitude of Christians to other religions and their adherents: Christ-centred spirituality "paves the way for a true universalism. The more Christcentered we are, the more able we become to break down or lower the partition walls, open ourselves to one another across the boundaries, and build community in diversity" (Chacko 2000:66).

But it is especially the Holy Spirit who works in other religions and among people of other faiths. As Stanley Samartha argues, it is not a "question of whether the Holy Spirit is active in others' experience but...where and how the Spirit is active there" (cited in Kim 2000:175). And if God, through his Spirit, is directly involved with the whole of humanity everywhere in the world, then it goes without saying that people everywhere come into contact with God, that they are gripped by God and that they bear witness to this in their words and deeds. People of other faiths are people who have met and consciously choose to serve God. This means that the congregation of Christ which is called to be a witness may also expect to be the recipient of witness from people of other cultures and faiths concerning the magnalia Dei, the great and wondrous deeds of God, namely God's salvific encounter with them, and the faith, hope and love that this encounter has engendered in their lives and communities. Through the religious experience of people of other faiths, through their response to God's revelatory initiative, Christians could be led to new, fresh understandings of their own faith $^{6}$.

\subsubsection{Mission}

This view of things bears important ramifications for the understanding of Christian mission. By and large, Christian churches have been

$6 \quad$ For a brief but clear discussion of various positions on the relationship between Christ and the Spirit in relation to the question of revelation and salvation in other religions see Wijsen (2007:162-170). 
aware that they have a witnessing task, namely that their life and work must be intentionally directed toward the world in which they exist. External missionary and diaconal outreach, along with its correlate, internal spiritual growth, is vital to the existence and meaning of the church. But the understanding of what mission is, has changed considerably through the years. There were those who already fairly early on in the modern era objected to the way mission was customarily conceived of and carried out.

The old perception of mission as word proclamation of the gospel and as a movement from the North to the South and the East to carry the gospel to cultures and peoples cast in terms of idolatry, superstition and unbelief, began to undergo modification from the very beginnings of the ecumenical movement in the early decades of the $20^{\text {th }}$ century. For example, the missionary method whereby people were called to abandon the traditional culture of their fathers and mothers came in time to be seen as highly presumptuous and intolerable. It is now generally accepted that Christian churches everywhere in the world are called to be agents of the contextualisation and inculturation of the gospel, namely, they are duty bound to bring the gospel into rapport with the existential situations, the actual social and cultural settings of the people among whom they have been mandated by Christ to work.

\subsubsection{The correlativity of perceptions and insights}

It is clear that all of these newer perceptions and insights are intimately related. The way Christians perceive mission will directly affect their attitude toward other religions, and, conversely, their attitude toward other religions will have an immediate bearing on their view of mission. Expressed in another way, serious and honest reflection on mission, on one hand, and on the relationship between Christianity and other religions, on the other, are dynamically interrelated. Together these two sets of reflection can be likened to an unending series of interlocking, interdependent cogwheels: fresh views regarding the stance that Christianity should assume a position relative to other faiths produces a new apprehension of mission, and further reflection on this new understanding of mission, in turn, energises a renewal of exploration in the area of interreligious relations, and so on.

\subsection{Recent attitudes and models of theology of religion}

It is through this process of theological and spiritual reassessment 
that many Christians of all stripes and persuasions, both ecumenicals and evangelicals, Catholics and Orthodox, have been or are being led to exchange their former exclusivist opinions for an inclusivist or even pluralist conception of the appropriate stance in respect of religious traditions different from their own?

One of the most popular models of theology of religion at present is that of relativising pluralism, which maintains that all religions are just so many paths all radiating around and leading to one and the same goal or end; this means that there is no essential difference between the various religions. Notwithstanding their popularity, however, these models of great-equaliser pluralism are unsatisfactory on at least one important count, namely, their colonialist character: what religiously others think is in essence no different from what I think and hence, though it may seem otherwise, in reality they think what I think, which actually means they think what I want them to think. To borrow an apt phrase coined by the investigative journalist Philip Gourevitch to define the nature of power, these models "make others inhabit your story of their reality" (Gourevitch 2000:48). As O'Grady and Scherle have aptly observed, though a pluralist theology of interreligious relations claims to be an alternative to what are termed objectionable exclusivist or inclusivist models, it itself turns out to be "both exclusivist, in its claim to present a perspective by which the truth of religions can be judged, and inclusivist, in its claim to embrace all religious approaches to this truth" (O'Grady \& Scherle 2007:7). In the final analysis the refusal or failure of the advocates of relativist pluralism to recognise essential differences and genuine uniqueness among the religions constitutes an offensive refusal and failure to take people of other faiths and their religious traditions seriously.

Recently, however, an intriguing and convincing alternative pluralist approach has been offered by Mark Heim (2001) in his book The Depth of the Riches: A Trinitarian Theology of Religious Ends. Heim maintains that the religious communities of the world do not all pursue the same goal but rather a diversity of goals and hence do not constitute relative entities. The various religions are paths to

7 Because of the different currents within Christianity, Christians will of course continue to assume a variety of stances vis-à-vis specific other religions; activist Christians, for example, would likely view contemplative Sufism differently than mystically inclined Christians would. 
various religious ends and consequently exhibit pronounced and even profound differences. The understanding of salvation, beatitude, relations with the divine differ from religion to religion. Heim shows how various religious ends fit in with and therefore can be grounded in the fullness of the divine life of the triune God, Father, Son and Holy Spirit. This being the case, the possibility exists that these alternative religious ends carry a deep eschatological significance, meaning that they may continue throughout and beyond time and present history, which means, in turn, that Christians, while remaining fully committed to their own faith, could and should respect and honour these other religious ends. Moreover, this kind of radical acceptance and affirmation of interreligious diversity and difference, Heim rightly maintains, does not preclude dialogue and witness but on the contrary makes them possible and meaningful.

Acceptance of diversity and difference does not of course rule out the possibility of necessary interreligious and intra-religious criticism. As O'Grady and Scherle rightly state, any apposite theology of religion or interreligious relations needs to include not only reflections by a religion "on the observation of other religions from the outside" but also "theological reflection" by a religion upon itself (O’Grady \& Scherle 2007:8). Without inner-religious critique, inter-religious criticism will be biased and invalid: religions will then identify other religions "either as paganism, as a mistaken, enforced way of life, or as heresy" (O'Grady \& Scherle 2007:9). Theology of religion cannot do without "a comparison of the ways in which the respective religions exercise religious critique of their own primary religion". Every religion, thus, is subject to critical examination from within and without as to whether it is internally coherent, straightforward, generally accessible, compatible with the deepest intentions of its holy scripture(s) and the traditions in which it stands; whether it is "good" or "bad" for people and society; whether it brings healing and salvific well-being or causes anxiety, distress and suffering; whether it seeks to convince by moral authority or coerce by any means of force.

Today increasing numbers of Christians are coming to realise that God is revealed in and through diversity and on the basis of that realisation would want to endorse a statement found in the report of Section I of the WCC mission conference held in San Antonio in 1990: "We cannot point to any other way of salvation than Jesus 
Christ; at the same time we cannot set limits to the saving power of God" (cited in Bosch 1991:489). And they would want to embrace "the abiding paradox of asserting both ultimate commitment to one's own religion and genuine openness to another's" (cited in Bosch 1991:483). This is the approach which would seem to commend itself most convincingly, an approach which affirms that the commitment of Christians to Christ does not prevent them from recognising God's grace and activity everywhere among all peoples; an approach which both allows and encourages Christians to accept all that is authentic and good and right in the faith and religious and moral practice of believers from other religious traditions; an approach, in short, which is as exclusive as necessary and as inclusive as possible.

The question confronting us ever more urgently today is how to bring about connectivity, how to foster convivance and establish networks of exchange between and among the various religions for the purpose of bridging divisions of hatred and suspicion and promoting justice, reconciliation and peace. How can existing walls of separation between religions be broken down and replaced with neighbouring open verandas? One important potential means of achieving open interreligious exchange and living together is the pursuit and practice of inter-religious dialogical communication and exchange.

\section{DIALOGUE}

The underlying assumption of dialogue is that despite very real differences and even significant disparities between cultures and religions there is a basic stratum of human commonalities that makes it possible for people to communicate with one another and to discover points of contact with those belonging to traditions other than their own. Some extremist post-modern thinkers tend to deny the existence of such commonalities and to take what I would term anthropological atomisation as their staring point. Such atomisation, if it really existed, would render any genuine, meaningful interhuman sharing impossible ${ }^{8}$. Contrary to this view, however, it is

8 It would also mean, of course, that there is ipso facto no possibility for grand narratives, which even though they have often proved to be susceptible to abuse and misuse by power or winner elites are, I would argue, essential for the development and maintenance of true human psychological and spiritual wellbeing. 
plainly evident that there are many human commonalities: experiences, fears, questions, joys and sorrows that people everywhere share. One could point in this connection to Bavinck's concept of universal religious consciousness with its attendant riddles of human existence to which we referred above. People everywhere share a sense of the divine or the transcendent, a sense of right and wrong, of justice and injustice. There are fundamental elements of human existence, basic aspects of human life here on earth entailing questions to which religions speak. If such ontological and epistemological commonalities did not exist, intercultural and interreligious communication could not exist. The very possibility of dialogue, thus, presupposes the existence of an anthropological floor of fundamental human commonalities.

\subsection{Preconditions for dialogue}

Dialogue, if it is to be genuine and successful, cannot be entered into cold and without further ado. It takes careful mental, psychological and spiritual preparation to engage meaningfully in dialogue. Integrity, honesty and trust are the indispensable preconditions and essential ingredients of healthy, salutary interpersonal and interhuman relations, including those between and among differing cultures and religions. Taken together, integrity, honesty and trust are, it appears to me, the essence of what the Apostle Paul called "love" and Jesus "the pearl of great price". Faith and hope, said Paul, are also crucially important, but love is the greatest. The trouble is, love and openness toward the culturally and religiously other are in short supply in our world. As is well known, things in short supply do not come cheap. When the demand for something exceeds its supply it becomes expensive: the greater the demand for something and the more restricted its supply, the more costly it becomes.

Emotions such as hatred, distrust and suspicion are readily available commodities in our world and therefore can be easily and "cheaply" obtained - they are only costly to their objects or victims. But love and openness toward the other, short in supply, are dear and can even become costly in the extreme to those who dedicate themselves to their practice: St Francis of Assisi (11811226), Mother Theresa, Beyers Naude, and so many others who were concerned to follow as best they could the supreme example of God in Jesus Christ, about whom St Francis said, Deus semper minor, semper major, that is to say, in becoming ever smaller, preeminently and finally in the babe in the crib and the suffering Son 
of Man on the Cross, God becomes ever greater. Followers of this example are deeply aware that discipleship does not permit of ease. One could put it this way: hatred and distrust of the other are "inexpensive" in the short run for those who entertain these emotions but extremely costly for everyone in the long run, whereas love and openness toward the other can be and sometimes are exceedingly costly in the short run for those who practice them but a great bargain for everyone in the long run.

To sum up, the qualities of respect, openness and trust discussed above are sine-qua-non prerequisites for interreligious dialogue which, in my view, consists ideally of four closely interrelated, interdependent equal components and which is thus, properly considered, quadripartite in nature.

\subsection{The four parts of dialogue}

The first level of interreligious colloquy is what may be termed the dialogue of histories. This dialogue begins with a serious analysis of past relations between or among the religions involved. What stance have they assumed with respect to one another? And more importantly, what was or is the position they occupy vis-à-vis each other on the political, social, and economic planes? It is at this level of dialogue that questions of justice and injustice, power and domination, wealth and poverty come to the fore. Interreligious conflict, division and hatred is very often occasioned by exploitation and oppression via forces and structures with which a certain religion is or has been either rightly or wrongly identified in local, national or global contexts. In such settings the first thing religions and religious believers need to do is engage in a dialogue of histories, which invariably recognises the victim of injustice as the proper subject and the perpetrator of that wrong as the proper object of any reconciliation that might emerge from this dialogical exchange.

The second tier of discussion among religions is the dialogue of theologies, whose purpose is to remove interreligious nescience and misunderstanding and to foster respect and tolerance among people of differing faiths. As Jacques Maritain states, each participant in this kind of dialogue recognises the right of the other interlocutors to "deny... and to contradict" the truth to which he or she holds "and to speak their own mind", on the grounds that they do not want for truth but seek it "in their own way" (Maritain 1965:29). 
This level of dialogue offers a means of gaining a sense of the deepest meaning and intention of one another's religious tenets and thus a way of breaking through communalist apprehensions of religion. Moreover, if the parties involved open themselves truly and fully to the divinely inspired truth that enlightens all people of faith, this type of dialogue might yield a new interreligious hermeneutics, an auxiliary tool that could be employed to arrive at a deeper understanding of the divine will for human-kind, a fuller comprehension of the sense and significance of life and the world, of injustice, conflict and reconciliation.

It should be obvious from this that participation in a dialogue of theologies by no means requires the adoption of a stance of uncritical relativism or an attitude of detachment with respect to one's own religion. Maritain asserts that we are duty bound to open ourselves and attend to the other's position and conviction in an unfeigned, fair and tolerant manner (Maritain 1965:24). But this kind of open-minded approach to the other is possible "only when a man is firmly and absolutely convinced of a truth, or of what he holds to be a truth" (Maritain 1965:29). An attitude of disengagement from one's own faith tradition, far from being a mark of desirable openness, would seem rather to be a sign of lack of commitment. As an astute Dutch observer has pointed out, this appears to be the case with much of European Christianity at the moment: one notices a certain nonchalance on the part of Western Christians who, in the context of interreligious encounter, "prefer not to talk about faith because it is irrelevant for" them, or who exhibit a "spiritual poverty" resulting from fundamental confusion regarding their faith (Valkenberg 2000:32). Secure religious identity is the very foundation of authentic interreligious dialogue. In order to have proper dialogue at any level, the partners have to know where they stand.

An interesting point here is that knowledge of this nature is quickened and enhanced by the proximity of other religions and religious believers: "It is only through encounter with the other that I acquire an idea of who I am" (Valkenberg 2000:33). For example, the presence of Islam in Europe, as a modern European Muslim leader has observed, can provide the opportunity for Europeans to think about who they are and what they believe (Ramadan 2000). Inter-religious reconciliation requires interfaith understanding, and the latter can be achieved only if the partners in dialogue can 
communicate with each other as committed believers at the spiritual level.

The third stratum of interreligious conversation is the dialogue of spiritualities. In the Christian ecumenical view, religious faith itself, in the sense of basic trust in God, acceptance of acceptance by God (cf Moltmann 1971:165), is an exceptionally important key to the realisation of interhuman reconciliation, because on the foundation of this trust it becomes possible to accept the different other freely and fully. "God is 'for us' and therefore we can and must be 'with each other' and not 'against each other" (Moltmann 1972:48) $)^{9}$. On that account, it may be argued that from the Christian perspective interreligious colloquy certainly does not preclude and should definitely include interfaith witnessing to the truth as one has received, perceives, experiences and believes it. In fact the truthclaims of the various religions, based on the authority of holy scriptures and living traditions, would appear strongly to imply an obligation to interfaith witness.

At this level of dialogue religious believers would talk together heart to heart about their deepest fears and highest hopes, desiring both "to understand" and "to be understood" (Wijsen 2007:171). Their aim would be to effect a respectful exchange of truth-claims, core beliefs and convictions, existential religious feelings. They would share spiritualities of reconciliation, relate accounts of redemption and sustenance to one another, narratives regarding salvation, namely the means whereby the walls of division between God and man, man and man, and man and nature are broken down. They would engage in mutual witness to beliefs in respect of the elemental questions of human existence. New discoveries about one another's faith convictions may lead the partners in the dialogue of spiritualities to a broader, more inclusive understanding of the consortium vitae divinae (participation in the divine life).

The fourth level of interreligious discourse is the dialogue of life. There are undeniably real theological and spiritual differences and contextual peculiarities among the religions of the world, but there are also matters and concerns, such as injustice and poverty, which should be and in increasing measure are becoming of high

9 'Gott ist 'für uns,' darum können en sollen wir 'miteinander' und 'nicht gegeneinander' sein". 
salience to all of them alike. As Frans Wijsen observes: "Interreligious dialogue...cannot confine itself to the problem of pluralism", but must also take full account of the matter of "power and domination" and the "problem of poverty" (Wijsen 2007:188). Though religion has often been misused and in some areas of the world still is unscrupulously employed in the service of evil, exploitation and self-serving power plays, it can be of genuinely significant help in the struggle to meet the high goal of addressing the challenges of conflict and ameliorating the manifold situations of human suffering we face in our globalised world. But if religion is to fulfil this potential in any kind of effective way, the various religions will have to join hands and become involved in a sharing of energies, bending their best efforts to the development of collaborative actions of renewal and transformation, namely to the establishment of what have been called "integrative synergies", among themselves but also between themselves and civil governments along with other secular institutions, visionary movements and moral agencies. Religion, thus, could make a genuine impact in terms of the resolution of conflict and interhuman reconciliation if the religions, rising above narrow ideological, national or ethnic considerations, would work together as a diaconal ensemble in pursuit of the shared human aspiration to alleviate poverty and injustice at both the global and local level. Broad interreligious solidarity with the poor and the victims of injustice would be a most effective way of engendering conditions favourable to the emergence of interhuman reconciliation.

\section{COLLECTIVE OBLIGATION}

In principle the quest for an interreligious coexistence that is open, peaceful and cooperative constitutes an ongoing global challenge and charge that is the same for all religions and religious people everywhere. But materially speaking neither the challenge nor the way it is worked out will be the same for everyone. Indeed, it goes without saying that this calling and obligation requires to be articulated and given shape locally and contextually. The encounter between theocentric religions will be different from that between a logocentric religion and a primary or primal one. Moreover, circumstances vary, sometimes extremely. There are urban, suburban and rural situations; situations defined by power and powerlessness, domination of (religious) haves by (religious) have-nots; conflictive situations and relatively irenic ones. There are contexts shot through 
with racism, communalism, poverty, sexism, gender inequalities. Societies differ and there are manifold cultures and subcultures within societies. All of which means, of course, that there is no one, single way of meeting this challenge that fits all needs and circumstances. Dialogue and interreligious convivance must be developed and pursued creatively and intelligently in close harmony with the spirit of a particular place and time, whereby full account is taken of existing social, political and religious realities. But the challenge itself and the charge to practice interreligious dialogue at all four of the levels described above and to build and maintain convivial relations among people and religions remain in force and are crucially important. In the globalised, pluralist world in which we presently find ourselves, such convivance, such harmonious living together is absolutely prerequisite to the security and wellbeing of humanity.

\section{Consulted literature}

Bach, M 1993. Strange sects and curious cults. Reprint. New York: Barnes and Noble.

Bavinck, J R 1966. The Church between the temple and mosque. Grand Rapids: Eerdmans.

-, 1989. Religieus besef en christelijk geloof. Kampen: Kok (reprint of the original publication by Kok in 1949).

Bosch, D J 1991. Transforming mission: Paradigm shifts in theology of mission. Maryknoll: Orbis.

Chacko, M 2000. Interpreting society: A study of the political theology of $M M$ Thomas and its implications for mission. Amsterdam: Free University Press.

Gort, J and Vroom H 2002. Religion, Conflict and Reconciliation, in Gort, J, Jansen, H \& Vroom, H (eds), Religion, conflict and reconciliation: Multifaith ideals and realities, Amsterdam and New York: Editions Rodopi, 3-10.

Gourevitch, P 2000. We wish to inform you that tomorrow we will be killed with our families: Stories from Rwanda. London: Picador.

Heim, S M 2001. The depth of the riches: A Trinitarian theology of religious ends. Grand Rapids: Eerdmans.

Jüngel, E 2000. To tell the world about god: The task for the mission of the Church on the threshold of the third millennium, in International Review of Mission 89/352, 203-216.

Kelly, J N D 1965. Early Christian doctrines. London: Adam \& Charles Black.

Kim, K 2000. Post-modem mission: A paradigm shift in David Bosch's theology of mission? in International Review of Mission 85/352, 172-79. 
Lutzbetak, L 1998. The Church and cultures. Maryknoll: Orbis.

McDowell, J 1983. Handbook of today's religions. New York: Thomas Nelson Publishers.

Maritain, J 1965. On the use of philosophy: Three essays. New York: Atheneum.

Moltmann, J 1971. Mensch: Christliche Anthropologie in den Konflikten der Gegenwart. Stuttgart: Kreuz-Verlag.

-, 1972. Die Sprache der Befreiung: Predigten und Besinnungen, München: Chr. Kaiser-Verlag.

O'Grady, J \& Scherle, P 2007. Ecumenics in the 21st century: Plumbing the relationships of theology, interreligious dialogue and peace studies, in O'Grady, J \& Scherle P (eds), Ecumenics from the rim: Explorations in honour of John D'Arcy, May, Berlin: LIT Verlag, 3-20.

Rahner, K 1962. Schriften zur Theologie, V. Einsiedeln: Verlaganstalt Benziger \& Co.

Ramadan, T 2000. Trying to bridge a great divide, in Time Magazine, November 11,84 .

Reitsma, B J 1999. Religieuze ervaringen en de Geest van God, in Soteria 16(2), 2-10.

Sundermeier, T 1991. Religion, in Dictionary of the Ecumenical Movement, Grand Rapids: Eerdmans / Geneva: WCC Publications, 856-57.

Valkenberg, P 2000. De ene God belijden te midden van Moslims en Joden, in Allerwegen 31(40), 29-33.

Wijsen, F 2007. Seeds of conflict in a haven of peace: From religious studies to interreligious studies in Africa. Amsterdam \& New York: Editions Rodopi. 